\title{
Is there a role for carbohydrate restriction in the treatment and prevention of cancer?
}

\author{
Rainer J Klement ${ }^{1 *}$ and Ulrike Kämmerer ${ }^{2}$
}

\begin{abstract}
Over the last years, evidence has accumulated suggesting that by systematically reducing the amount of dietary carbohydrates (CHOs) one could suppress, or at least delay, the emergence of cancer, and that proliferation of already existing tumor cells could be slowed down. This hypothesis is supported by the association between modern chronic diseases like the metabolic syndrome and the risk of developing or dying from cancer. CHOs or glucose, to which more complex carbohydrates are ultimately digested, can have direct and indirect effects on tumor cell proliferation: first, contrary to normal cells, most malignant cells depend on steady glucose availability in the blood for their energy and biomass generating demands and are not able to metabolize significant amounts of fatty acids or ketone bodies due to mitochondrial dysfunction. Second, high insulin and insulin-like growth factor (IGF)-1 levels resulting from chronic ingestion of CHO-rich Western diet meals, can directly promote tumor cell proliferation via the insulin/IGF1 signaling pathway. Third, ketone bodies that are elevated when insulin and blood glucose levels are low, have been found to negatively affect proliferation of different malignant cells in vitro or not to be usable by tumor cells for metabolic demands, and a multitude of mouse models have shown antitumorigenic properties of very low CHO ketogenic diets. In addition, many cancer patients exhibit an altered glucose metabolism characterized by insulin resistance and may profit from an increased protein and fat intake. In this review, we address the possible beneficial effects of low $\mathrm{CHO}$ diets on cancer prevention and treatment. Emphasis will be placed on the role of insulin and IGF1 signaling in tumorigenesis as well as altered dietary needs of cancer patients.
\end{abstract}

Keywords: Ketogenic diet, cancer, review, low carbohydrate diet, cachexia, insulin, insulin-like growth factor 1 (IGF1)

\section{Introduction}

When defining the factors of a healthy lifestyle that aims at preventing a disease like cancer, a logical approach is to compare individuals that get the disease with those that don't. Cancer, which might be considered a disease of civilization, has consistently been reported to be very rare among uncivilized hunter-gatherer societies [1-4]. This observation makes sense from an evolutionary perspective from which it is reasonable to assume that the lifestyle factors that protect our genome against tumorigenesis have been selected for early in the history of the genus homo when humans lived as hunter-gatherers [5]. In particular, the time since the neolithic revolution,

\footnotetext{
* Correspondence: Klement_R@klinik.uni-wuerzburg.de

'Department of Radiation Oncology, University hospital of Würzburg, D97080 Würzburg, Germany

Full list of author information is available at the end of the article
}

which meant the transition from foraging and nomadism to agriculture and settlement, spans a fraction less than $1 \%$ of human history. Thus, the switch from the "caveman's diet" consisting of fat, meat and only occasionally roots, berries and other sources of carbohydrate ( $\mathrm{CHO})$ to a nutrition dominated by easily digestible $\mathrm{CHOs}$ derived mainly from grains as staple food would have occurred too recently to induce major adoptions in our genes encoding the metabolic pathways. This is even more the case for the changes that occurred over the past 100 years, in particular the switch from labor in the field to a sedentary lifestyle and an increase in the consumption of easily digestible $\mathrm{CHOs}$ with high glycemic indices (GIs), leading to diseases of civilization that are strongly associated with the so-called Western way of life [6]. Despite a large heterogeneity in regional occupation, modern hunter-gatherers share certain
C Biomed Central

두 2011 Klement and Kämmerer; licensee BioMed Central Ltd. This is an Open Access article distributed under the terms of the Creative Commons Attribution License (http://creativecommons.org/licenses/by/2.0), which permits unrestricted use, distribution, and reproduction in any medium, provided the original work is properly cited. 
lifestyle factors that are not frequently met in Westernized societies, including regular physical activity, sun exposure, sufficient sleep, low chronic stress and the lack of foods that would also not have been available to our pre-neolithic ancestors. While there is already compelling evidence for the beneficial roles of regular physical activity and sufficient vitamin $\mathrm{D}$ in the prevention and treatment of cancer, the influence of the altered nutritional patterns in the Western diet is less clearly defined.

\section{Modern hunter-gatherers' diet}

Data from 229 hunter-gatherer societies included in the revised Ethnographic Atlas indicate that hunter-gatherer diets differ from typical Western ones in basically two aspects: first, a strong reliance on animal foods (45-65\% of energy or E\%) and second, the consumption of lowGI plant foods such as vegetables, fruits, seeds and nuts [7]. This is consistent with stable isotope studies of human fossils $[8,9]$. As a consequence, the amount and type of carbohydrates in the typical western diet differ markedly from the ones that our genes adapted to. In particular, Cordain and colleagues estimated that modern hunter-gatherers derived about 22-40 E\% from CHOs and 19-30 E\% from protein, which is lower and higher, respectively, than recommended by Western food agencies. Recently, Ströhle \& Hahn confirmed that the energy derived from CHOs - despite being dependent upon geographic latitude and ecological environment - in modern hunter-gatherers is markedly lower than in Westernized societies [10]. High CHO intake, in particular in the form of sugar and other high GI foods, has been linked to modern diseases like metabolic syndrome [11], Alzheimer's disease [12,13], cataract and macula degeneration [14-16] and gout [17]. Intriguingly, with the possible exception of Alzheimer's disease [18], the occurrence and prognosis of cancer seems positively associated with both the prevalence of these diseases [19-28] and the GI and glycemic load (GL) of the diet [29-32]; this implies a possible role of high $\mathrm{CHO}$ intake in cancer as well.

In this review, we are going to present some arguments that support the hypothesis that lowering the amount of CHOs in the diet can have direct beneficial effects on the prevention and treatment of malignant diseases. The main focus will be on very low $\mathrm{CHO}$, ketogenic diets as an effective supportive therapy option for cancer patients.

\section{Tumor cell metabolism - it's all about glucose}

That there exists an intimate connection between $\mathrm{CHOs}$ and cancer has been known since the seminal studies performed by different physiologists in the 1920s. Treating diabetic patients, A. Braunstein observed in 1921 that in those who developed cancer, glucose secretion in the urine disappeared. Further, culturing tissue of benign and malign origin in glucose-containing solutions, he quantified the much higher consumption by cancer tissue compared to muscle and liver [33]. One year later, R. Bierich described the remarkable accumulation of lactate in the micromilieu of tumor tissues [34] and demonstrated lactate to be essential for invasion of melanoma cells into the surrounding tissue [35]. The most accurate and well known experiments were published by Otto Warburg and colleagues from 1923 on [36-38]. Warburg observed that tumor tissue ex vivo would convert high amounts of glucose to lactate even in the presence of oxygen (aerobic glycolysis), a metabolic phenotype now referred to as the Warburg effect. This meant a sharp contrast to normal tissue which was known to exhibit the Pasteur effect, i.e., a decrease of glucose uptake and inhibition of lactate production under aerobic conditions. Today, the Warburg effect is an established hallmark of cancer, i.e., a pathological capability common to most, if not all, cancer cells [39]. At first sight, the reason why many cancers should run preferentially on glucose to produce energy seems counter-intuitive: basic biochemistry textbooks tell us that glycolysis partially oxidizes the carbon skeleton of one mole of glucose to two moles of pyruvate, yielding two moles of ATP and NADH. In normal cells under normoxic conditions, pyruvate is oxidized in the mitochondria by the enzyme pyruvate dehydrogenase, creating acetyl-CoA which is further utilized in the tricarboxylic acid cycle (TCA or Krebs cycle) to yield a total of $32+$ moles of ATP. Thus, the oxidation of pyruvate in the mitochondria supplies $30+$ additional moles of ATP compared to its reduction to lactate via lactate dehydrogenase A (LDHA), which happens in case of insufficient oxygen levels or - in case of cancer cells - due to the Warburg effect.

\section{Possible causes for the "Warburg effect"}

Over the past years, however, it has become increasingly clear that malignant cells compensate for this energy deficit by up-regulating the expression of key glycolytic enzymes as well as the glucose transporters GLUT1 and GLUT3, which have a high affinity for glucose and ensure high glycolytic flux even for low extracellular glucose concentrations. This characteristic is the basis for the wide-spread use of the functional imaging modality positron emission tomography (PET) with the glucose-analogue tracer ${ }^{18}$ F-fluoro-2-deoxyD-glucose (FDG) (Figure 1). There are mainly four possible drivers discussed in the literature that cause the metabolic switch from oxidative phosphorylation to aerobic glycolysis in cancer cells. The first one is mitochondrial damage or dysfunction [40], which was already proposed by 


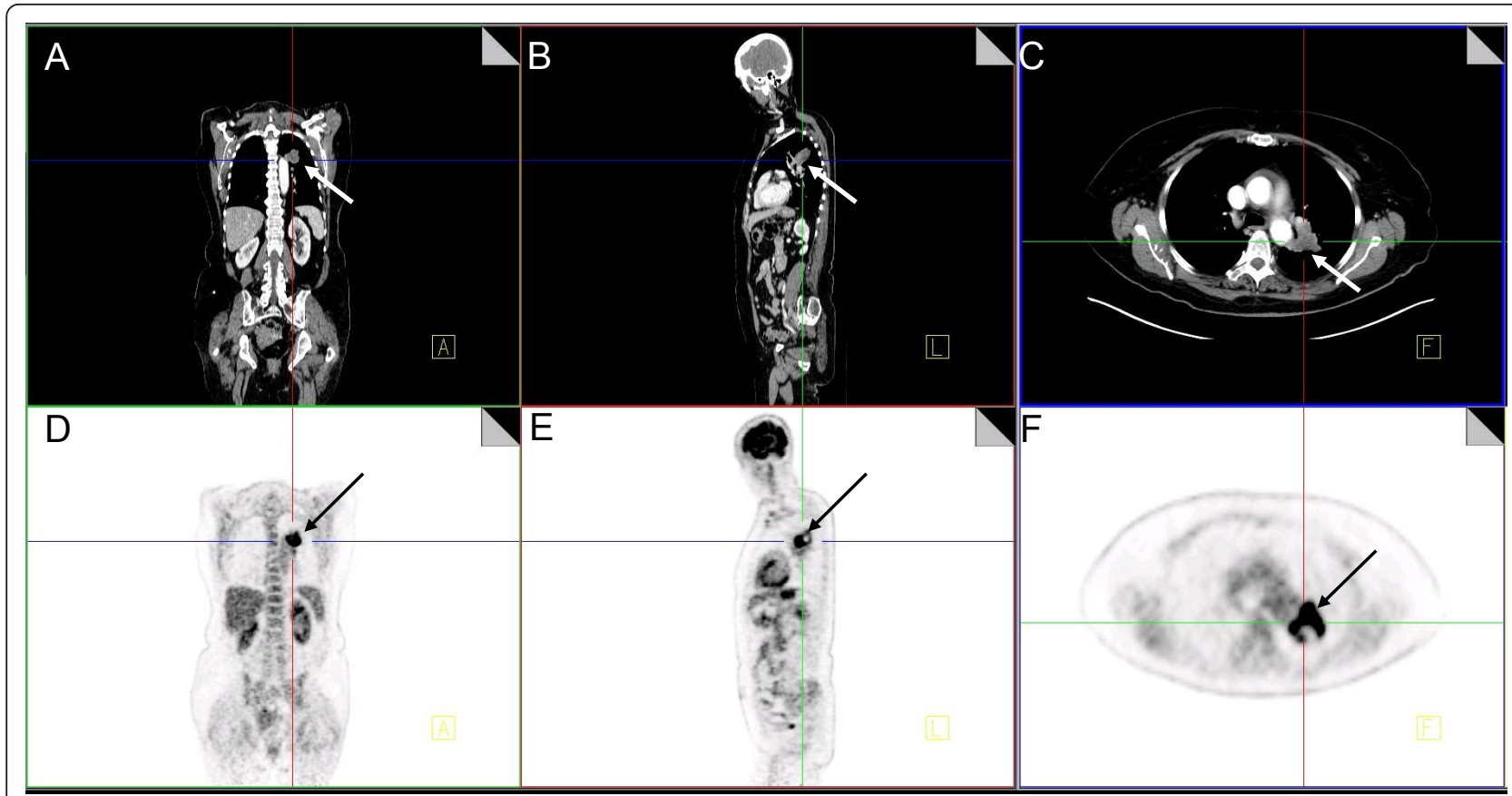

Figure 1 PET image of a patient with a left central lung carcinoma (arrows). Note also the high FDG uptake by the kidneys (Fig D), brain and myocard (Figure E). Source: PET/CT Imaging Centre, University Hospital of Würzburg.

Warburg himself as the cause for tumorigenesis [41]. Somatic mutations in mitochondrial DNA (mtDNA) and certain OXPHOS genes can lead to increased production of reactive oxygen species (ROS) and accumulation of TCA cycle intermediates (succinate and fumarate) that trigger the stabilization of hypoxia inducible factor (HIF)-1 $\alpha$, inactivation of tumor suppressors including p53 and PTEN and upregulation of several oncogenes of the phosphoinositide 3-kinase (PI3K)/Akt/mammalian target of rapamycin (mTOR) signaling pathway [42]. In tumor cells, Akt plays a major role in resisting apoptosis and promoting proliferation, and it does so by reprogramming tumor cell metabolism [43-45]. Akt suppresses $\beta$-oxidation of fatty acids [46], but enhances de novo lipid synthesis in the cytosol $[47,48]$. Akt also activates mTOR, a key regulator of cell growth and proliferation that integrates signaling from insulin and growth factors, amino acid availability, cellular energy status and oxygen levels $[49,50]$. In cancer cells, mTOR has been shown to induce aerobic glycolysis by up-regulating key glycolytic enzymes, in particular through its downstream effectors c-Myc and HIF-1 $\alpha$. Both of these transcription factors are involved in the expression of pyruvate kinase M2, a crucial glycolytic enzyme for rapidly proliferating cells [51].

HIF- $1 \alpha$ is further important for the adaption to hypoxia by increasing the expression of glycolytic enzymes including GLUT1 and hexokinase (HK)II as well as several angiogenic factors $[49,52]$. The observation that certain malignant cells are able to use both glycolysis and OXPHOS under aerobic conditions has been taken to argue that mitochondrial dysfunction alone is not a sufficient cause for the Warburg effect [53]. Indeed, somatic mutations in most oncogenes and tumor suppressor genes have been shown to directly or indirectly activate glycolysis even in the presence of oxygen. As described above, they do so mainly by hyperactivating major metabolic signaling pathways such as the insulin-like growth facor-1 receptor (IGFR1)-insulin receptor (IR)/PI3K/Akt/mTOR signaling pathway (Figure 2). In principle, hyperactivation of this pathway can occur at several points from alterations in either upstream (receptor) or downstream (transducer) proteins and/or disruption of negative feedback loops via loss-of-function mutations in suppressor genes $[44,45,54]$. Thus, genetic alterations in oncogenes and tumor suppressor genes are a second possible cause for the Warburg effect.

As a third mechanism, with advanced tumorigenesis, non-mutation induced stabilization of HIF- $1 \alpha$ occurs through a lack of oxygen in hypoxic tumor regions and contributes to increased glycolysis. Proliferation of aggressive tumors proceeds too fast for concurrent vascularization, so that hypoxic regions will develop. Because the diffusion coefficients for glucose are larger than for oxygen, these regions rely heavily on glycolysis. Hypoxic cancer cells are particularly radio- and chemoresistant. In PET-studies, tumor areas with high FDG 


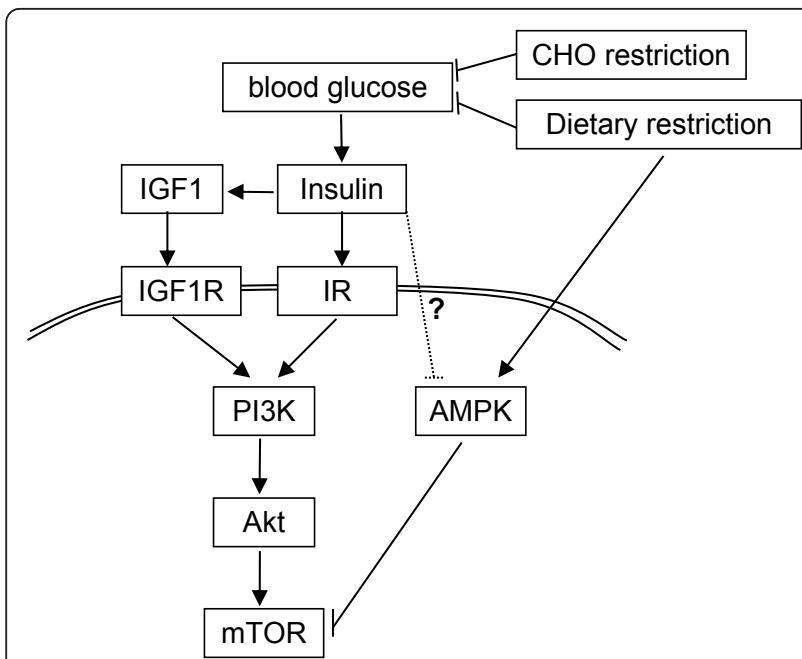

Figure 2 The IGF1R-IR/PI3K/Akt/mTOR pathway and its manipulation through diet. Elevations in blood glucose concentrations lead to secretion of insulin with subsequent elevation of free IGF1. Binding of insulin and IGF1 to their receptor tyrosine kinases induces autophosphorylation of the latter which leads to subsequent activation of PI3K by one of at least three different pathways [54]. Further downstream, PI3K signaling causes phosphorylation and activation of the serine/threonine kinase Akt (also known as protein kinase B). Akt activates mammalian target of rapamycin (mTOR), which itself induces aerobic glycolysis by upregulating key glycolytic enzymes, in particular via its downstream effectors c-Myc and hypoxia inducible factor (HIF)-1 $1 \alpha$. mTOR is negatively affected through activation of AMPK, which can be achieved by dietary restriction [67]. In addition, a possible negative interaction between insulin and AMPK is discussed in vivo [60].

uptake have been consistently linked to poor prognosis $[55,56]$ and are now being considered as important biological target volumes to receive dose escalations in radiation treatment [57].

\section{The impact of insulin and IGF1}

Finally, chronic activation of the IGFR1-IR/PI3K/Akt survival pathway through high blood glucose, insulin and inflammatory cytokines has been proposed as a cause of carcinogenesis [30,58,59] and switch towards aerobic glycolysis. In this theory, hyperactivation of the IGFR1-IR signalling pathway does not occur primarily through somatic gene mutations, but rather through elevated concentrations of insulin and IGF1, allowing for more ligands binding to their receptors. Interestingly, gain-of-function mutations resulting in ligand-independent overactivation of both IGFR1 and IR are uncommon [60]. Furthermore, loss-of-function of the tumor suppressor PTEN may result in hypersensitivity to insulin/IGF1-mediated activation of the IGFR1-IR pathway rather than constitutive downstream activation [60]. Thus, it seems possible that high levels of insulin and IGF1 in the microenvironment favor cell survival and evolution towards malignancy instead of apoptosis in DNA-damaged cells. Indeed, both hyperglycemia and hyperinsulinemia are predictors of cancer occurrence and cancer-related mortality [23,25,26]. This highlights the link between the metabolic syndrome and cancer on the one hand and cancer and lifestyle factors like nutrition on the other. As indicated in Figure 2, restriction of dietary $\mathrm{CHOs}$ would counteract this signalling cascade by normalizing glucose and insulin levels in subjects with metabolic syndrome, in this way acting similar to calorie restriction/fasting [61,62]. Indeed, it has been shown in healthy subjects that $\mathrm{CHO}$ restriction induces hormonal and metabolic adaptions very similar to fasting [63-66]. Dietary restriction is able to inhibit mTOR signalling through a second, energy-sensing pathway by stimulating phosphorylation of AMP-activated protein kinase (AMPK) [67]. In vitro, AMPK phosphorylation is sensitive to the ratio of AMP/ATP within the cell; in vivo, however, concentrations of glucose and other nutrients are kept fairly stable throughout calorie restriction, suggesting that hormones such as insulin and glucagon might play a more dominant role in regulating AMPK and thus mTOR activation [60]. This may open a second route to mimic the positive effects of calorie restriction through $\mathrm{CHO}$ restriction (Figure 2).

\section{Glycolysis: beneficial for tumor cells}

Besides the ability to grow in hypoxic environments, a high glycolytic rate has several additional advantages for the malignant cell: First, it avoids the production of ROS through OXPHOS. Second, the phosphometabolites that accumulate during glycolysis can be processed in the pentose phosphate pathway for biosynthesis of nucleic acids and lipids. Similarly, overexpession of Akt induces an increased flow of pyruvate-derived citrate from the mitochondrion into the cytosol, where it is used for lipid biosynthesis. Third, a tumor cell focusing on glycolysis no longer relies on intact mitochondria and may evade apoptotic signalling which is linked to mitochondrial function. In addition, the genes and pathways that up-regulate glycolysis are themselves antiapoptotic [40]. Fourth, high glycolytic activity produces high levels of lactate and $\mathrm{H}^{+}$ions which get transported outside the cell where they directly promote tumor aggressiveness [68] through invasion and metastasis, two other hallmarks of cancer. For this purpose, glycolytic tumor cells often show overexpression of monocarboxylate transporters (MCTs) and/or $\mathrm{Na}^{+} / \mathrm{H}^{+}$exchangers [69] that allow them to effectively remove large amounts of $\mathrm{H}^{+}$ions. For MDA-MB-231 breast cancer cells it has been shown that lactate drives migration by acting as a chemo-attractant and enhances the number of lung metastasis in athymic nude mice [70]. Lactate can also be taken up and used as a fuel by some malignant cells, 
and oxidative tumor cells have been shown to co-exist with glycolytic ones (both stromal and malignant) in a symbiotic fashion [71]. In glioma cells, lactate upregulates and activates the matrix metalloproteinase (MMP)2 which degrades the extra-cellular matrix and basement membrane [72]. Activation of MMPs may also occur in the microenvironment through low $\mathrm{pH}$ values in a similar way as discussed for carious decay of the dentin organic matrix through lactate released by cariogenic bacteria [73]. Acidification of the microenvironment further induces apoptosis in normal parenchymal and stromal cells $[74,75]$ and therefore provides a strong selective growth advantage for tumor cells that are resistant to low pH-induced apoptosis [76,77].

\section{Glucose availability as a promoter of cancer growth}

Taken together, increased glucose flux and metabolism promotes several hallmarks of cancer such as excessive proliferation, anti-apoptotic signalling, cell cycle progression and angiogenesis. It does so, however, at the expense of substrate inflexibility compared to normal cells. It is clear that the high proliferative phenotype can only be sustained as long as a steady supply of substrates for ATP production is available. Thus, with progressive tumorigenesis, cancer cells become more and more 'addicted' to aerobic glycolysis [53] and vulnerable to glucose deprivation. Indeed, several studies have shown that malignant cells in vitro quickly lose ATP and commit apoptosis when starved of glucose [78-80]. Masur et al. showed that diabetogenic glucose concentrations $(11 \mathrm{mM})$ compared to physiological ones $(5.5$ $\mathrm{mM}$ ) lead to altered expression of genes that promote cell proliferation, migration and adhesion in tumor cell lines from several organs including breast, colon, prostate and bladder [81]. Adding insulin to the high-glucose medium further enhanced proliferation rates by $20-40 \%$ and promoted activation of the PI3K pathway. The question is whether altered blood glucose levels have similar effects on tumor growth in vivo. Theoretically, low blood glucose might cut some of the most hypoxic tumor cells from their diffusion-limited fuel supply. Gatenby and Gillies originally proposed this mechanism as an explanation for necrotic areas often found within tumor tissue [82], but they later revised this hypothesis based on a mathematical model that predicted only a modest decline of glucose concentrations with distance from the closest blood vessel [69]. There are, however, several lines of evidence pointing towards a strong correlation between blood glucose levels and tumor growth in vivo that might indicate other important effects mediated by glucose. For example, the reduction of plasma glucose levels in tumor-bearing animals induced through calorie restriction may be responsible, directly or indirectly, for the significantly prolonged survival compared to normal-fed controls [83,84]. In 1962, Koroljow reported the successful treatment of two patients with metastatic tumors by an insulin-induced hypoglycemic coma [85]. Hyperglycemia, on the other hand, is a predictor of poor survival in patients with various cancers $[22,26,86-88]$ and has been positively correlated to an increased risk for developing cancer at several sites including the pancreas, esophagus, liver, colon, rectum, stomach and prostate in large cohort studies $[25,89,90]$.

\section{Indirect effects of glucose availability}

Besides delivering more glucose to the tumor tissue, hyperglycemia has two other important negative effects for the host: First, as pointed out by Ely and Krone, even modest blood glucose elevations as they typically occur after a Western diet meal competitively impair the transport of ascorbic acid into immune cells [88,91]. Ascorbic acid is needed for effective phagocytosis and mitosis, so that the immune response to malignant cells is diminished. Second, it has been shown in vitro and in vivo that hyperglycemia activates monocytes and macrophages to produce inflammatory cytokines that play an important role also for the progression of cancer [92-94] (see below). Third, high plasma glucose concentrations elevate the levels of circulating insulin and free IGF1, two potent anti-apoptotic and growth factors for most cancer cells [60]. Free IGF1 is elevated due to a decreased transcription of IGF binding protein (IGFBP)1 in the liver mediated by insulin [95]. Due to expression of GLUT2, the $\beta$-cells of the pancreas are very sensitive to blood glucose concentration and steeply increase their insulin secretion when the latter exceeds the normal level of $\sim 5 \mathrm{mM}$. In the typical Western diet consisting of three meals a day (plus the occasional $\mathrm{CHO}$-rich snacks and drinks), this implies that insulin levels are elevated above the fasting baseline over most of the day. Both insulin and IGF1 activate the PI3K/ Akt/mTOR/HIF-1 $\alpha$ pathway by binding to the IGF1 receptor (IGF1R) and insulin receptor (IR), respectively (Figure 2). In addition, insulin stimulates the release of the pro-inflammatory cytokine interleukin (IL)- 6 from human adipocytes [96]. Thus, it could be hypothesized that a diet which repeatedly elevates blood glucose levels due to a high GL provides additional growth stimuli for neoplastic cells. In this respect, Venkateswaran et al. have shown in a xenograft model of human prostate cancer that a diet high in $\mathrm{CHO}$ stimulated the expression of IRs and phosphorylation of Akt in tumor tissue compared to a low $\mathrm{CHO}$ diet [97]. In colorectal [27], prostate [24] and early stage breast cancer patients $[23,98]$ high insulin and low IGFBP-1 levels have been associated with poor prognosis. These findings again underline the importance of controlling blood sugar and 
hence insulin levels in cancer patients. Dietary restriction and/or a reduced $\mathrm{CHO}$ intake are straightforward strategies to achieve this goal.

\section{Altered nutritional needs of cancer patients}

Cancer patients and those with metabolic syndrome share common pathological abnormalities. Since 1885, when Ernst Freund described signs of hyperglycemia in 70 out of 70 cancer patients [99], it has been repeatedly reported that glucose tolerance and insulin sensitivity are diminished in cancer patients even before signs of cachexia (weight loss) become evident [100-102]. Both diabetes and cancer are characterized by a common pathophysiological state of chronic inflammatory signalling and associated insulin resistance. In cancer patients, insulin resistance is thought to be mediated by an acute phase response that is triggered by pro-inflammatory cytokines such as tumor necrosis factor (TNF)- $\alpha$ [101] and IL-6 [103]. In animal and human studies, removal of the tumor resulted in improved glucose clearance, suggesting that these cytokines are secreted, at least in part, from the tumor tissue itself $[104,105]$. The impact on the metabolism of the host is illustrated in Figure 3.
In the liver, the inflammatory process leads to increased gluconeogenesis that is fuelled by lactate secreted from the tumor as well as glycerol from fatty acid breakdown and the amino acid alanine [106] from muscle proteolysis. Gluconeogenesis is an energy-consuming process and might contribute to cancer cachexia by increasing total energy expenditure. Despite increased lipolysis, hepatic production of ketone bodies is usually not enhanced in cancer patients $[107,108]$. This is in contrast to starvation, where the ketone bodies acetoacetate and $\beta$-hydroxybutyrate counteract proteolysis by providing energy for the brain and muscles [109]. In muscle, glucose uptake and glycogen synthesis are inhibited already at early stages of tumor progression, while fatty acid oxidation remains at normal levels or is increased $[110,111]$. In the latter case, more fat has to be provided from lipolysis in the adipose tissue. In addition, muscles progressively lose protein to provide amino acids for hepatic synthesis of acute-phase proteins and as precursors for gluconeogenesis. Thus, insulin resistance contributes to fat loss and muscle wasting, the two hallmarks of cancer cachexia. At the same time, it makes more glucose in the blood available for tumor cells.

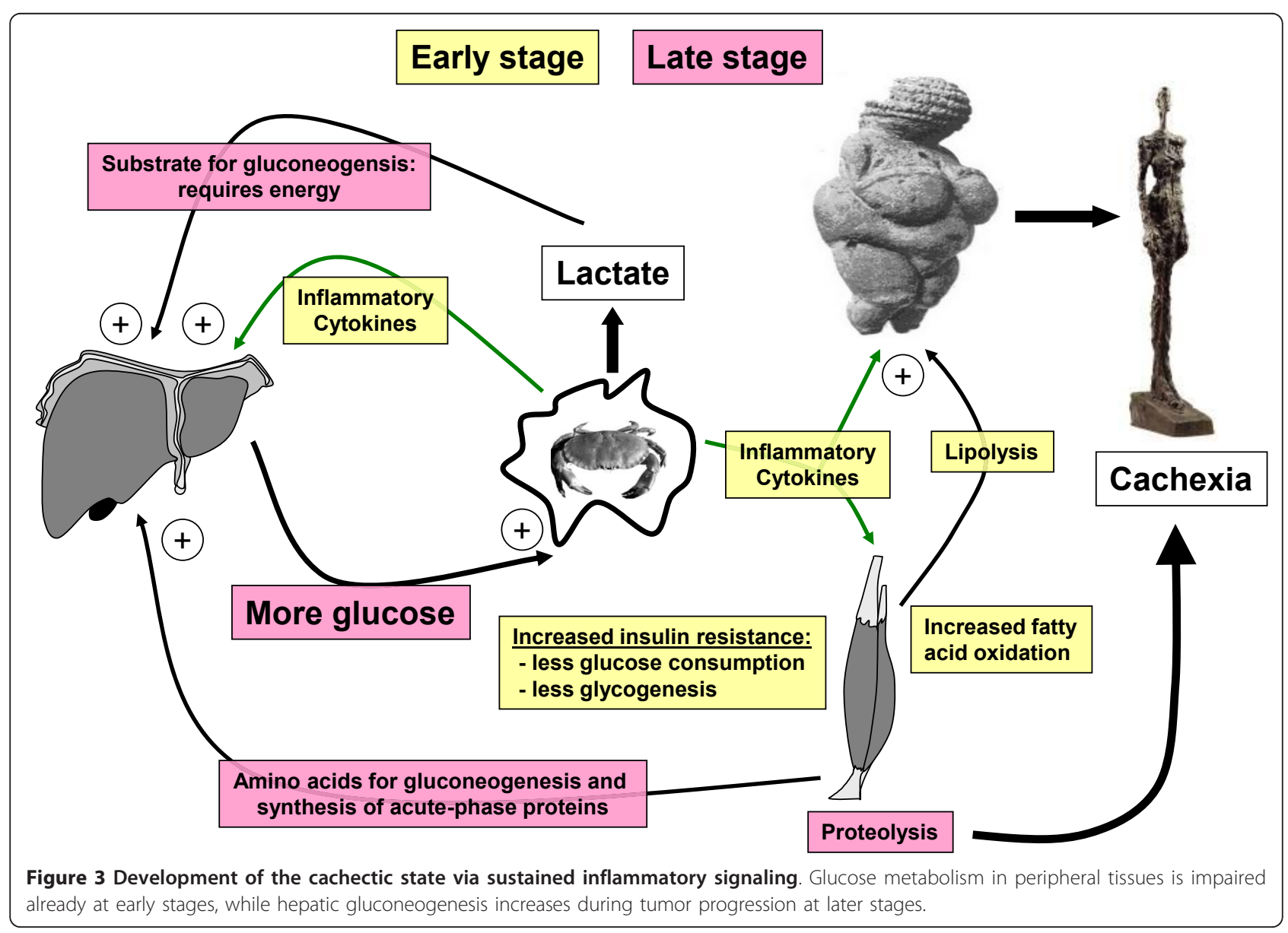


Fat and ketone bodies: anti-cachectic effects

It therefore seems reasonable to assume that dietary carbohydrates mainly fuel malignant cells which express the insulin-independent glucose transporters GLUT1 and GLUT3, while muscle cells are more likely to benefit from an increased fat and protein intake. This was summarized as early as in 1977 by C. Young, who stated that lipid sources predominate the fuel utilization of peripheral tissue of patients with neoplastic disease compared to healthy subjects [112]. In addition, most malignant cells lack key mitochondrial enzymes necessary for conversion of ketone bodies and fatty acids to ATP $[40,113,114]$, while myocytes retain this ability even in the cachectic state [107]. This led some authors to propose a high-fat, ketogenic diet (KD) as a strategy to selectively improve body composition of the host at the expense of the tumor $[113,115,116]$. The traditional KDs, which recommended protein and $\mathrm{CHO}$ to account, in combination, for roughly $20 \mathrm{E} \%$ (in the incorrect assumption that they were equivalent due to gluconeogenesis) and fat for the remaining $80 \mathrm{E} \%$, have been widely used to treat childhood epilepsia since the 1920 s [117]. KDs are also used to treat adiposity [118] and currently adult epilepsy [119]. In the 1980s, Tisdale and colleagues investigated the effects of a ketogenic diet consisting mainly of medium chain triglycerides (MCTs) on two aggressive animal tumor models that were known to lack the ability to utilize ketone bodies. While the diet had no effect on rats bearing the Walker 256 sarcoma [120], it decreased the cachectic weight loss in proportion to its fat content in mice bearing the mousespecific colon carcinoma MAC16 [121]. For the latter, they further proved an anti-cachectic effect of a ketogenic diet in which the MCTs were replaced with long chain triglycerides (LCTs), although to a somewhat lesser extent [122]. Contrary to LCTs, MCTs do not require transport in chylomicrones, but readily reach the liver where they are metabolized to yield high amounts of ketone bodies. Interestingly, administration of insulin was able to reduce the weight loss similar to the ketogenic MCT diet, but at the expense of a $50 \%$ increase in tumor size, which could be counteracted by addition of $\beta$-hydroxybutyrate in the drinking water [123]. The supporting effect of insulin on tumor growth has been known since 1924, when Händel and Tadenuma described the nourishing effect of insulin on tumor tissue in an animal model [124], showing evidence that reducing insulin might reduce tumor growth.

\section{Clinical studies on fat and cachexia}

Clinical studies investigating the anti-cachectic effects of high-fat diets are, however, rare. Fearon et al. administered a 70\% MCT diet supplemented with $\beta$-hydroxybutyrate parenterally to five late-stage cachectic patients.
After seven days on the diet, mean body weight had increased by $2 \mathrm{~kg}$ and their physical performance status had improved [125]. Nebeling et al. investigated the effects of a MCT-based ketogenic diet taken ad libitum (60\% MCT oil, $20 \%$ protein, $10 \%$ CHO, 10\% other fats) on body weight and glucose metabolism in two pediatric patients with advanced-stage astrocytoma. Within 7 days on the diet, blood glucose levels had decreased to normal, while glucose uptake by the tumor estimated from FDG-PET scans had decreased by an average value of $21.8 \%$. Notably, body weight remained stable throughout the study period of 8 weeks. In a randomized controlled study, Breitkreuz et al. showed that by supplementing the normal diet of 11 under-nourished, non-diabetic patients suffering from metastatic gastro-intestinal cancers with a fat-enriched liquid supplementation for 8 weeks, it was possible to reverse the loss of body weight and lean tissue mass and to improve several quality-oflife parameters in the treatment group, while the control group continued to lose body and lean tissue weight [126]. The supplement contained 66\% energy from fat, of which $45 \%$ were monounsaturated, $27 \%$ saturated (both LCT and MCT) and 28\% polyunsaturated; mean energy intake ranged between 1000 and $2000 \mathrm{kcal} /$ day and tended to be higher in patients receiving the additional fat drink.

\section{The benefits of mild ketosis}

The study of Breitkreuz et al. shows that ketosis might not be necessary to improve the cachectic state of cancer patients. In recent years, however, more evidence has emerged from both animal and laboratory studies indicating that cancer patients could benefit further from a very low $\mathrm{CHO} \mathrm{KD}$. In their mouse models, Tisdale et al. already noted that the KD not only attenuated the cachectic effects of the tumor, but also that the tumors grew more slowly (although they did not attribute this to a direct anti-tumor effect of $\beta$-hydroxybutyrate). Tumor growth inhibition through a KD has now been established in many animal models, is supported by a few clinical case reports, and laboratory studies have begun to reveal the underlying molecular mechanisms.

\section{In vitro studies}

More than 30 years ago, Magee et al. were the first to show that treating transformed cells with various, albeit supra-physiological, concentrations of $\beta$-hydroxybutyrate causes a dose-dependent and reversible inhibition of cell proliferation [116]. Their interpretation of the results that "...ketone bodies interfere with either glucose entry or glucose metabolism..." has been confirmed and further specified by Fine et al., who connected the inhibition of glycolysis in the presence of abundant ketone 
bodies to the overexpression of uncoupling protein-2 (UCP-2), a mitochondrial defect occurring in many tumor cells [127]. In normal cells, abundant acetyl-CoA and citrate from the breakdown of fatty acids and ketone bodies would inhibit key enzymes of glycolysis to ensure stable ATP levels; in tumor cells, however, the same phenomenon would imply a decrease in ATP production if the compensatory ATP production in the mitochondria was impaired. For several colon and breast cancer cell lines, Fine et al. showed that the amount of ATP loss under treatment with acetoacetate was related to the level of UCP-2 expression.

Very recently, Maurer et al. demonstrated that glioma cells - although not negatively influenced by $\beta$-hydroxybutyrate - are not able to use this ketone body as a substitute for glucose when starved of the latter, contrary to benign neuronal cells [128]. This supports the hypothesis that under low glucose concentrations, ketone bodies could serve benign cells as a substitute for metabolic demands while offering no such benefit to malign cells.

\section{Animal studies}

To our knowledge, the first and - with a total of 303 rats and nine experiments - most extensive study of a KD in animals was conducted by van Ness van Alstyne and Beebe in 1913 [129]. Experiments were divided into two classes: in the first class, rats in the treatment arm were fed a CHO-free diet consisting of casein and lard for several weeks before plantation of a Buffalo sarcoma, while the control arm received either bread only or casein, lard and lactose. Rats on the CHO-free diet not only gained more weight than the controls, but also exhibited much less tumor growth and mortality rates, the differences being "... so striking as to leave no room for doubt that the diet was an important factor in enabling the rats to resist the tumor after growth had started." In a second class of experiments using either the slow-growing Jensen sarcoma or the aggressive Buffalo sarcoma, the rats were put on the $\mathrm{CHO}$-free diet on the same day that the tumor was planted. This time, differences between the treatment and control groups were "... so slight that ... one is left in no doubt of the ineffectiveness of non-carbohydrate feeding begun at the time of tumor implantation." Interestingly, this parallels the observation of Fearon et al. that rats who started to receive a $K D$ at the same day as tumor transplantation did not differ from controls in either body or tumor weight after $14 \mathrm{~d}$ [120]. In these rats, it was noted that despite persistent ketosis, blood glucose levels were not significantly lower than in controls which were also fed ad libitum. This stability of blood glucose, independent of ketosis, was subsequently confirmed in studies in which mice were fed ad libitum on a KD
[84,114,121-123,130] although two studies reported a drop in blood glucose concentrations compared with the control group $[116,131]$. In the study of Magee et al., however, diet was presented as a liquid vegetable oil and energy intake was not monitored, allowing for the possibility that the animals underate voluntarily, in this way consuming a "caloric restricted KD" used in several experimental settings from the Seyfried lab $[84,114,132]$, which was shown therein to be superior to the unrestricted KD in tumor growth control. That "caloric restriction" per se can hamper tumor growth has been impressively demonstrated already in 1942 by A. Tannenbaum in a series of comprehensive mouse models with different mouse strains and tumor induction types [133]. Throughout all experimental series, a strict restriction of food intake (impeding weight gain) several weeks before inducing tumorigenesis by application of 3,4 benzpyrene decreased the appearance rate and appearance time of tumors in the diet mice compared to the ad libitum controls. Notably, the calorierestricted diet was composed of 53\% CHOs compared to $69 \%$ in the control group. Despite a lack of data on blood glucose and ketone body levels, it could be speculated that the strict restriction of food per se (to 50-60\% of the control group) induced a ketotic state and thus the ketones were - at least to some extend - responsible for the effects observed.

In Table 1, we summarize the main results of various mouse studies that determined the effects of KDs on tumor growth and host survival. The results seem to indicate an anti-tumor effect of ketosis. Freedland et al. indeed reported that the mice with the highest levels of ketone bodies had the longest survival times in a human prostate cancer xenograft model [134]. But other studies suggest that there are further possible factors to consider. Seyfried et al. used linear regression to show that plasma glucose and IGF1 levels are a better predictor of tumor growth than ketone bodies in a murine astrocytoma model [84]. Tumor growth in this as well as in a follow-up [114] study was only retarded when the KD had been restricted to induce body weight loss, again underlining the effect of caloric restriction per se. This contrasts with other studies showing growth-inhibitory effects of unrestricted or higher-caloric KDs despite neither decreases in blood glucose concentration nor body weight loss compared with a control group $[130,134,135]$. According to Otto et al., whose diet had been enriched in MCT and omega-3 fatty acids, fat quality might play a role in explaining these results [130]. The situation in humans might be different as well, as for example Fine et al. found no correlation between calorie intake or weight loss and disease progression in ten patients on an unrestricted KD [136] (see also below). 
Table 1 Animal studies that have investigated the effects of a KD on tumor progression and host survival

\begin{tabular}{|c|c|c|c|c|c|c|c|c|c|c|c|}
\hline animals & $\mathrm{n}$ & tumor & feeding & $\mathrm{C} / \mathrm{P} / \mathrm{F}$ & $\begin{array}{l}\text { major fat } \\
\text { source }\end{array}$ & $\begin{array}{c}\text { diet } \\
\text { initiation }\end{array}$ & $\begin{array}{c}\text { diet } \\
\text { duration }\end{array}$ & $\begin{array}{l}\text { BW vs. } \\
\text { controls }\end{array}$ & $\begin{array}{l}\text { BG vs. } \\
\text { controls }\end{array}$ & other effects vs. controls & Ref. \\
\hline & & & & $(\mathrm{E} \%)$ & & (d) & (d) & & & & \\
\hline $\begin{array}{l}\text { C57BL/6 } \\
\text { mice }\end{array}$ & 18 & $\begin{array}{c}\text { B16 } \\
\text { melanoma }\end{array}$ & ad libitum & $\begin{array}{l}0 / 0 / \\
100^{1}\end{array}$ & $\begin{array}{c}\text { PUFA } \\
\text { vegetable oil }\end{array}$ & 0 & 14 & - & $\downarrow^{b}$ & $\begin{array}{l}\text { lower number of lung } \\
\text { metastases }{ }^{b}\end{array}$ & $\overline{[116]}$ \\
\hline $\begin{array}{l}\mathrm{BALB} / \mathrm{C} \\
\text { mice }\end{array}$ & 20 & $\begin{array}{l}\text { Medina- } \\
\text { Oborn- } \\
\text { Danielson } \\
\text { mammary } \\
\text { tumor }\end{array}$ & $\begin{array}{l}\text { restricted } \\
\text { to } 60 \mathrm{E} \% \\
\text { of control }\end{array}$ & $\begin{array}{c}30 / 60 / \\
5\end{array}$ & $\begin{array}{l}\text { hydrogenated } \\
\text { vegetable oil }\end{array}$ & $\sim 14$ & 70 & $\downarrow$ & $\downarrow^{c}$ & mortality rate $\downarrow^{c}$ & [83] \\
\hline $\begin{array}{l}\text { NMR1 } \\
\text { mice }\end{array}$ & $\begin{array}{l}> \\
15\end{array}$ & $\begin{array}{l}\text { MAC16 } \\
\text { colon } \\
\text { carcinoma }\end{array}$ & ad libitum & $\ldots / . . . / 80$ & MCT emulsion & 8 & 20 & $\uparrow$ & - & $\begin{array}{l}50 \% \text { less weight loss }{ }^{b} \text {; left35\% } \\
\text { less tumor weight }\end{array}$ & [121] \\
\hline \multirow[t]{3}{*}{$\begin{array}{l}\text { NMR1 } \\
\text { mice }\end{array}$} & $\ldots$ & $\begin{array}{l}\text { MAC16 } \\
\text { colon } \\
\text { carcinoma }\end{array}$ & ad libitum &..$/ . . / 80$ & & $14-21$ & 9 & $\uparrow$ & - & $36 \%$ less weight loss ${ }^{a}$ & [123] \\
\hline & & & & & & & & & & $32 \%$ less tumor weight ${ }^{c}$ & \\
\hline & & & & & & & & & & less nitrogen output ${ }^{a}$ & \\
\hline $\begin{array}{l}\text { C57BL/6 } \\
\text { mice }\end{array}$ & 6 & $\begin{array}{c}\mathrm{CT}-2 \mathrm{~A} \\
\text { mouse } \\
\text { astrocytoma }\end{array}$ & $\begin{array}{l}\text { restricted } \\
\text { to } 60 \mathrm{E} \% \\
\text { of control }\end{array}$ & 0/8/92 & lard & 1 & 13 & $\downarrow^{3}$ & $\downarrow^{3}$ & $\begin{array}{l}80 \% \text { less tumor weight }{ }^{\text {b; }} \\
\text { plasma IGF1 levels } \downarrow \text { b3, }\end{array}$ & [84] \\
\hline $\begin{array}{l}\text { C57BL/6 } \\
\text { mice }\end{array}$ & 11 & $\begin{array}{c}\mathrm{CT}-2 \mathrm{~A} \\
\text { mouse } \\
\text { astrocytoma }\end{array}$ & ad libitum & $\begin{array}{c}3 / 17 / \\
80\end{array}$ & $\begin{array}{c}\text { soy oil } \\
\left.(\text { KetoCal })^{\circ}\right)\end{array}$ & 3 & $>8$ & - & - & $\begin{array}{l}\text { no significant differences in } \\
\text { either tumor weight, survival } \\
\text { or vascularity }\end{array}$ & [114] \\
\hline+ & + & + & & & & & & & & & \\
\hline \multirow[t]{2}{*}{$\begin{array}{l}\mathrm{BALB} / \mathrm{CJ} \\
\mathrm{SCID} \\
\text { mice }\end{array}$} & 14 & $\begin{array}{c}\text { U87 } \\
\text { glioblastoma }\end{array}$ & $\begin{array}{l}\text { restricted } \\
\text { to } 65-70 \\
\text { E\% of } \\
\text { control }\end{array}$ & $\begin{array}{c}3 / 17 / \\
80\end{array}$ & $\begin{array}{l}\text { soy oil } \\
\left(\text { KetoCal }^{\circ}\right)\end{array}$ & 3 & $>8$ & $\downarrow^{b}$ & $\downarrow^{b}$ & $\begin{array}{l}65 \%(\mathrm{CT}-2 \mathrm{~A})^{\mathrm{b}} \text { and } 35 \%(\mathrm{U} 87) \\
\text { cless tumor wet weight; }^{2}\end{array}$ & \\
\hline & & & & & & & & & & $\begin{array}{l}\text { longer survival }{ }^{\text {b; }} \text {; lower } \\
\text { number of blood vessels (both } \\
\text { tumors) }\end{array}$ & \\
\hline \multirow[t]{4}{*}{$\begin{array}{l}\mathrm{nu} / \mathrm{nu} \\
\text { mice }\end{array}$} & 20 & $\begin{array}{l}\text { LNCaP } \\
\text { human } \\
\text { prostate } \\
\text { cancer }\end{array}$ & ad libitum & $\begin{array}{l}10 / 45 / \\
45\end{array}$ & $\ldots$ & 14 & 63 & $\downarrow^{a}$ & $\ldots$ & $\begin{array}{l}\text { plasma insulin levels } \downarrow \text { c; } \\
\text { plasma IGF1 levels } \downarrow c^{c}\end{array}$ & [97] \\
\hline & & & & & & & & & & $45 \%$ less tumor volume ${ }^{a}$ & \\
\hline & & & & & & & & & & $43 \%$ less tumor dry weight & \\
\hline & & & & & & & & & & $\begin{array}{l}\text { decreased levels of } \\
\text { phosphorylated Akt (below } \\
\text { detected limits) and insulin } \\
\text { receptor in tumor tissue }\end{array}$ & \\
\hline $\begin{array}{l}\mathrm{SCID} \\
\text { mice }\end{array}$ & 25 & $\begin{array}{l}\text { LAPC-4 } \\
\text { human } \\
\text { prostate } \\
\text { cancer }\end{array}$ & $\begin{array}{l}\text { 9\% more } \\
\text { energy } \\
\text { than } \\
\text { control }\end{array}$ & $\begin{array}{c}0 / 16 / \\
84\end{array}$ & milk fat + lard & -24 & $>40$ & - & $\uparrow^{c}$ & longer survival ${ }^{\mathrm{b}}$ & [134] \\
\hline \multirow[t]{3}{*}{$\begin{array}{l}\text { NMRI } \\
\text { mice }\end{array}$} & 12 & $\begin{array}{l}23132 / 87 \\
\text { human } \\
\text { gastric } \\
\text { adenoma }\end{array}$ & ad libitum & $\begin{array}{l}0 / 14 / \\
86\end{array}$ & $\begin{array}{l}\text { cheese }+ \text { MCT } \\
+ \text { omega-3 oil }\end{array}$ & 0 & $>16$ & - & - & longer survival ${ }^{a}$; & [130] \\
\hline & & & & & & & & & & tumor growth rate $\downarrow^{c}$; & \\
\hline & & & & & & & & & & $\begin{array}{l}\text { larger necrotic area in tumors } \\
b\end{array}$ & \\
\hline $\begin{array}{l}\mathrm{C} 3 \mathrm{H} / \mathrm{HeN} \\
\text { mice }^{4}\end{array}$ & 5 & $\begin{array}{l}\text { squamous } \\
\text { cell car- } \\
\text { cinoma VII }\end{array}$ & ad libitum & $\begin{array}{l}16 / 58 / \\
26\end{array}$ & $\ldots$ & -7 & 16 & $\uparrow$ & $\downarrow$ & $41 \%$ less tumor volume ${ }^{d}$ & [131] \\
\hline $\begin{array}{l}\text { Foxn1nu } \\
\text { mice }\end{array}$ & 12 & $\begin{array}{l}\text { LNT-229 } \\
\text { glioma cells }\end{array}$ & ad libitum & $\begin{array}{c}0 / 13 / \\
36\end{array}$ & $\begin{array}{l}\text { flaxseed and } \\
\text { hempseed oil }\end{array}$ & 1 & $>63$ & - & - & $\begin{array}{l}\text { no significant differences in } \\
\text { survival, tumor growth and } \\
\text { plasma IGF1 levels }\end{array}$ & [128] \\
\hline
\end{tabular}

In all but one cases, control diets contained a minimum of $40 \% \mathrm{CHO}$. Diet initiation refers to the time of tumor cell plantation.

$\mathrm{SCID}=$ Severe Combined Immunodeficiency; C/P/F = ratio of CHO:protein:fat; $\mathrm{E} \%$ = percent of energy; $\mathrm{BW}=$ body weight; $\mathrm{BG}=$ blood glucose

${ }^{1}$ plus not further specified pellets on days 5,8 and $11 /^{2}$ plus $3 \mathrm{mg} / \mathrm{ml}$ beta-hydroxybutyrate in drinking water/ ${ }^{3}$ controls were fed a $\mathrm{KD}$ ad libitum, not high-CHO/

${ }^{4}$ similar results for Rag2M mice bearing human colorectal HCT-116 tumors/ ${ }^{\mathrm{a}} \mathrm{p}<0.005 ;{ }^{\mathrm{b}} \mathrm{p}<0.01 ;{ }^{\mathrm{c}} \mathrm{p}<0.05 ;{ }^{d} \mathrm{p}<0.1$ 
Concerning fat quality, Freedland et al. observed that a diet rich in corn oil might stimulate prostate cancer growth to a greater extent than one rich in saturated fat [134]. A recent study suggests, however, that tumor growth inhibition neither depends on fat quality nor ketone body levels [131]. In this case, mice injected with either murine squamous cell carcinoma or human colorectal carcinoma cells received a low $\mathrm{CHO}$, high-protein diet in which $\sim 60 \mathrm{E} \%$ was derived from protein, 10-15 $\mathrm{E} \%$ from $\mathrm{CHO}$ and $~ 25 \mathrm{E} \%$ from fat. No systemic ketosis was measured, yet tumors grew significantly less compared with a standard diet containing $55 \mathrm{E} \%$ from $\mathrm{CHO}$ and $22 \mathrm{E} \%$ from the same fat source. IGF1 levels and body weight remained stable, so these findings could not be attributed to one of these factors. There was, however, a significant drop in blood glucose, insulin and lactate levels, and a positive correlation between blood lactate as well as insulin levels and tumor growth was found. The study of Venkateskwaran et al. indicates that in prostate cancer insulin and/or IGF1 play major roles in driving tumor cell proliferation [97].

The diversity of these findings should not be surprising, given the variety of mice strains, tumor cell lines, diet composition and time of diet initiation relative to tumor planting. Instead, it seems remarkable that the same basic treatment, namely drastic restriction of $\mathrm{CHOs}$, apparently induces anti-tumoral effects via different pathways. Thus, it may depend on the circumstances which variables - including blood glucose, insulin, lactate, IGF1, fat quality and ketone bodies - are the best predictors of and responsible for the anti-tumor effects of very low $\mathrm{CHO}$ diets.

\section{Human studies}

Until now, no randomized controlled trials have been conducted to evaluate the effects of a KD on tumor growth and patient survival. It has to be noted in general, however, that any dietary intervention requiring a dramatic change of life style makes randomized studies nearly impossible - however, even prospective cohort studies are missing. There is only anecdotal evidence that such a diet might be effective as a supportive treatment. One study investigated whether a high-fat diet (80\% non-nitrogenous calories from fat) would inhibit tumor cell replication compared to a high-dextrose diet (100\% non-nitrogenous calories from dextrose) in 27 patients with gastro-intestinal cancers [137]. Diets were administered parenterally and cell proliferation assessed using thymidine labeling index on tumor samples. After 14 days, the authors found a non-significant trend for impaired proliferation in the high-fat group. Whether ketosis was achieved with this regime was not evaluated, but blood glucose levels were comparable in both trial groups. A very recent pilot trial demonstrated the feasibility of a low $\mathrm{CHO}$ up to a ketogenic regimen implemented for 12 weeks in very advanced outpatient cancer patients. Notably, severe side effects were not observed, nearly all standard blood parameters improved and some measures of quality of life changed for the better [138]. The first attempt to treat cancer patients with a long-term controlled KD was reported by L. Nebeling in 1995 for two pediatric patients with astrocytoma [139]. The results of those two cases were very encouraging and the diet was described in detail in another publication [140]. Implementing a KD with additional calorie restriction in a female patient with glioblastoma multiforme clearly demonstrated that this intervention was able to stop tumor growth [132]. This was achieved, however, on the expense of a dramatic weigh loss of $20 \%$ over the intervention period, which is no option for the majority of metastatic cancer patients being in a catabolic state. A first clinical study applying a non-restricted KD for patients with glioblastoma (ERGO-study, NHI registration number NCT00575146), which was presented at the 2010 ASCO meeting [141], showed good feasibility and suggested some anti-tumor activity. The protocol of another clinical interventional trial (RECHARGE trial, NCT00444054) treating patients with metastatic cancer by a very low $\mathrm{CHO}$ diet was published in 2008 [142], and preliminary data from this study presented at the 2011 ASCO-meeting showed a clear correlation between disease stability or partial remission and high ketosis, independent of weight loss and unconscious caloric restriction of the patients [136]. While a randomized study for the treatment of prostate cancer patents applying the Atkins diet (NCT00932672) is currently recruiting patients at the Duke University, another trial posted at the clinical trials database (ClinicalTrials.gov) is not yet open for recruitment (NCT01092247). Very recently, two Phase I studies applying a ketogenic diet based on $\mathrm{KetoCal}^{\circledR} 4: 1$ started recruitment at the University of Iowa, intended to treat prostate cancer patients (KETOPAN, NCT01419483) and non-small cell lung cancer (KETOLUNG, NCT01419587). Thus, in the future, several data should be available to judge whether this kind of nutrition is useful as either a supportive or even therapeutic treatment option for cancer patients.

\section{Is there a role for carbohydrate restriction in the prevention of cancer?}

"Prevention of cancer" can refer to either the inhibition of carcinogenesis per se or - once that cells made the transition to malignancy - the sufficient delay of tumor growth, so that it remains undetected and asymptomatic during a subject's lifespan. There is evidence that even modest $\mathrm{CHO}$ restriction may influence both of these mechanisms positively through various pathways. The 
IGF1R-IR pathway has already been discussed: once a potentially carcinogenic somatic mutation has occurred, the probability for carcinogenesis of a cell that is borderline between apoptosis and malignancy might be raised by high levels of insulin and IGF1 in the microenvironment. Once a cell became malignant, high insulin and IGF1 levels might accelerate proliferation and progression towards a more aggressive, glycolytic phenotype. In rats treated with the carcinogen $\mathrm{N}$-methyl-Nnitrosourea, it has been shown that lowering the $\mathrm{CHO}$ content of the diet from $60 \mathrm{E} \%$ to $40 \mathrm{E} \%$ with a simultaneous increase in protein was sufficient to lower postprandial insulin levels as well as decrease the appearance rate of tumors from $(18.2 \pm 1.3) \% /$ wk to $(12.9 \pm 1.4) \% /$ wk $(\mathrm{p}<0.05)$, however with no statistically significant effect on tumor latency and weight measured after $10 \mathrm{wk}$ [143]. Similarly, a recent study reported that NOP mice, which normally have a $70-80 \%$ chance of developing breast cancer over their lifetime due to genetic mutations, stayed tumor-free at 1 year of age when their calories from $\mathrm{CHO}$ were limited to $15 \%$, while almost half of those on a $55 \%$ CHO diet developed tumors [131]. Notably, only 3 out of 11 mice in the $15 \% \mathrm{CHO}$ group died with having a tumor compared to 7 out of 10 in the $55 \%$ CHO group; at death, significantly lower plasma insulin levels had been measured for the low $\mathrm{CHO}$ group. These results support the epidemiological $[25,29,31,32]$ and in vitro $[81,144]$ findings that high $\mathrm{CHO}$ diets, in particular those including high GI foods, promote mammary tumorigenesis via the sustained action of insulin.

Lower insulin levels may further increase the chance of intermittent ketosis, in particular if $\mathrm{CHO}$ restriction is combined with exercise, calorie restriction or intermittent fasting. Seyfried and Shelton [40] pointed out the possibility of ketone bodies to help in cancer prevention through their ability to protect the mitochondria from inflammation and ROS. Being more satiating than low-fat diets $[145,146]$, a low CHO diet would make it easier to avoid caloric overconsumption or to implement intermittent fasting as an additional lifestyle change [147].

\section{Avoidance of chronic inflammation}

Another potential benefit of low $\mathrm{CHO}$ diets might lie in their influence upon inflammatory processes that take place within various tissues. Inflammation is a wellestablished driver of early tumorigenesis and accompanies most, if not all cancers [148]. Chronic, 'smouldering' inflammation can both cause and develop along with neoplasia. There is evidence that chronic intake of easily digestible $\mathrm{CHOs}$ is able to promote such an inflammatory state in leukocytes and endothelial cells [94]. In obese individuals [149] and healthy subjects who underwent eccentric exercise training [150], the inflammatory state was further augmented postprandially through a high $\mathrm{CHO}$ intake, but not through high-fat, low $\mathrm{CHO}$ meals in the latter study. Maybe more importantly, even moderate $\mathrm{CHO}$ restriction has been shown to effectively target several important markers of atherosclerosis and type II diabetes, both of which are associated with chronic inflammation [151-157]. Forsythe et al. showed that in overweight individuals with dyslipidemia a very low $\mathrm{CHO}$ diet had a more favorable effect than a low fat diet in reducing several markers of inflammation [158]. Given these findings, it can be hypothesized that a diet with a low GL positively affects cancer risk through reducing postprandial hyperglycemia and the associated inflammatory response.

In this context, it is important to note that a low $\mathrm{CHO}$ diet offers further possibilities to target inflammation through omission or inclusion of certain foods. Usually, CHO restriction is not only limited to avoiding sugar and other high-GI foods, but also to a reduced intake of grains. Grains can induce inflammation in susceptible individuals due to their content of omega- 6 fatty acids, lectins and gluten $[159,160]$. In particular gluten might play a key role in the pathogenesis of auto-immune and inflammatory disorders and some malignant diseases. In the small intestine, gluten triggers the release of zonulin, a protein that regulates the tight junctions between epithelial cells and therefore intestinal, but also blood-brain barrier function. Recent evidence suggests that overstimulation of zonulin in susceptible individuals could dysregulate intercellular communication promoting tumorigenesis at specific organ sites [161].

Paleolithic-type diets, that by definition exclude grain products, have been shown to improve glycemic control and cardiovascular risk factors more effectively than typically recommended low-fat diets rich in whole grains [162]. These diets are not necessarily very low $\mathrm{CHO}$ diets, but focus on replacing high-GI modern foods with fruits and vegetables, in this way reducing the total GL. This brings us back to our initial perception of cancer as a disease of civilization that has been rare among hunter-gatherer societies until they adopted the Western lifestyle. Although there are certainly many factors contributing to this phenomenon, the evidence presented in this review suggests that reduction of the high $\mathrm{CHO}$ intake that accounts for typically $>50 \mathrm{E} \%$ in the Western diet may play its own important role in cancer prevention and outcome.

\section{Conclusions}

We summarize our main findings from the literature regarding the role of dietary $\mathrm{CHO}$ restriction in cancer 
development and outcome.

(i) Most, if not all, tumor cells have a high demand on glucose compared to benign cells of the same tissue and conduct glycolysis even in the presence of oxygen (the Warburg effect). In addition, many cancer cells express insulin receptors (IRs) and show hyperactivation of the IGF1R-IR pathway. Evidence exists that chronically elevated blood glucose, insulin and IGF1 levels facilitate tumorigenesis and worsen the outcome in cancer patients.

(ii) The involvement of the glucose-insulin axis may also explain the association of the metabolic syndrome with an increased risk for several cancers. $\mathrm{CHO}$ restriction has already been shown to exert favorable effects in patients with the metabolic syndrome. Epidemiological and anthropological studies indicate that restricting dietary $\mathrm{CHOs}$ could be beneficial in decreasing cancer risk.

(iii) Many cancer patients, in particular those with advanced stages of the disease, exhibit altered whole-body metabolism marked by increased plasma levels of inflammatory molecules, impaired glycogen synthesis, increased proteolysis and increased fat utilization in muscle tissue, increased lipolysis in adipose tissue and increased gluconeogenesis by the liver. High fat, low $\mathrm{CHO}$ diets aim at accounting for these metabolic alterations. Studies conducted so far have shown that such diets are safe and likely beneficial, in particular for advanced stage cancer patients.

(iv) $\mathrm{CHO}$ restriction mimics the metabolic state of calorie restriction or - in the case of KDs - fasting. The beneficial effects of calorie restriction and fasting on cancer risk and progression are well established. $\mathrm{CHO}$ restriction thus opens the possibility to target the same underlying mechanisms without the side-effects of hunger and weight loss.

(v) Some laboratory studies indicate a direct antitumor potential of ketone bodies. During the past years, a multitude of mouse studies indeed proved anti-tumor effects of KDs for various tumor types, and a few case reports and pre-clinical studies obtained promising results in cancer patients as well. Several registered clinical trials are going to investigate the case for a KD as a supportive therapeutic option in oncology.

\section{List of abbreviations}

AMPK: AMP-activated protein kinase; $\mathrm{CHO}$ : carbohydrate; $\mathrm{CT}$ : computed tomography; E\%: percentage of energy; FDG: ${ }^{18}$ F-fluoro-2-deoxyD-glucose; Gl: glycemic index; GL: glycemic load; HIF-1a: hypoxia inducible factor-1a; IGF: insulin like growth factor; IR: insulin receptor; KD: ketogenic diet; LCT: long chain triglycerides; MMP: matrix metalloproteinase; MCT: medium chain triglycerides; mTOR: mammalian target of rapamycin; PET: positron emission tomography; PI13K: Phosphoinositide 3-kinase; ROS: reactive oxygen species.

\section{Acknowledgements}

We are grateful to the two anonymous referees for their suggestions that helped to improve this paper. We also would like to thank Bill Lemke and Sebastian Baier for fruitful discussions and comments on a previous version of this paper. UK appreciates a research grant from the "Deutsche Gesellschaft für Ernährungsmedizin (DGEM)". This publication was funded by the German Research Foundation (DFG) and the University of Würzburg in the funding program Open Access Publishing.

\section{Author details}

${ }^{1}$ Department of Radiation Oncology, University hospital of Würzburg, D97080 Würzburg, Germany. ${ }^{2}$ Department of Obstetrics and Gynaecology, University hospital of Würzburg, D-97080 Würzburg, Germany.

\section{Authors' contributions}

RJK drafted the manuscript, UK drafted figures and parts of the manuscript, both authors finalized the manuscript. All authors have read and approved the final manuscript.

\section{Competing interests}

The authors declare that they have no competing interests.

Received: 11 August 2011 Accepted: 26 October 2011

Published: 26 October 2011

\section{References}

1. Levine I: Cancer among the American Indians and its bearing upon the ethnological distribution of the disease. J Cancer Res Clin Oncol 1910, 9:422-435

2. Orenstein AJ: Freedom Of Negro Races From Cancer. Br Med J 1923, 2:342.

3. Prentice G: Cancer Among Negroes. Br Med J 1923, 2:1181.

4. Brown GM, Cronk LB, Boag TJ: The occurrence of cancer in an Eskimo. Cancer 1952, 5:142-143.

5. Eaton SB, Konner M, Shostak M: Stone agers in the fast lane: chronic degenerative diseases in evolutionary perspective. Am J Med 1988, 84:739-749.

6. Carrera-Bastos P, Fontes-Villalba M, O'Keefe JH, Lindeberg S, Cordain L: The western diet and lifestyle and diseases of civilization. Research Reports in Clinical Cardiology 2011, 2:15-35.

7. Cordain L, Miller JB, Eaton SB, Mann N: Macronutrient estimations in hunter-gatherer diets. Am J Clin Nutr 2000, 72:1589-1592.

8. Hu Y, Shang H, Tong H, Nehlich O, Liu W, Zhao C, Yu J, Wang C, Trinkaus E, Richards MP: Stable isotope dietary analysis of the Tianyuan 1 early modern human. Proc Natl Acad Sci USA 2009, 106:10971-10974.

9. Richards MP: A brief review of the archaeological evidence for Palaeolithic and Neolithic subsistence. Eur J Clin Nutr 2002, 56:16, p following 1262.

10. Ströhle A, Hahn A: Diets of modern hunter-gatherers vary substantially in their carbohydrate content depending on ecoenvironments: results from an ethnographic analysis. Nutrition Research 2011, 31:429-435.

11. Weinberg SL: The diet-heart hypothesis: a critique. J Am Coll Cardiol 2004, 43:731-733.

12. Henderson ST: High carbohydrate diets and Alzheimer's disease. Med Hypotheses 2004, 62:689-700.

13. Seneff S, Wainwright G, Mascitelli L: Nutrition and Alzheimer's disease: the detrimental role of a high carbohydrate diet. Eur J Intern Med 2011, 22:134-140.

14. Chiu CJ, Milton RC, Gensler G, Taylor A: Dietary carbohydrate intake and glycemic index in relation to cortical and nuclear lens opacities in the Age-Related Eye Disease Study. Am J Clin Nutr 2006, 83:1177-1184.

15. Chiu CJ, Hubbard LD, Armstrong J, Rogers G, Jacques PF, Chylack LT Jr, Hankinson SE, Willett WC, Taylor A: Dietary glycemic index and carbohydrate in relation to early age-related macular degeneration. Am J Clin Nutr 2006, 83:880-886.

16. Kaushik S, Wang JJ, Flood V, Tan JS, Barclay AW, Wong TY, Brand-Miller J, Mitchell P: Dietary glycemic index and the risk of age-related macular degeneration. Am J Clin Nutr 2008, 88:1104-1110. 
17. Dessein $\mathrm{PH}$, Shipton EA, Stanwix AE, Joffe BI, Ramokgadi J: Beneficial effects of weight loss associated with moderate calorie/carbohydrate restriction, and increased proportional intake of protein and unsaturated fat on serum urate and lipoprotein levels in gout: a pilot study. Ann Rheum Dis 2000, 59:539-543.

18. Roe CM, Fitzpatrick AL, Xiong C, Sieh W, Kuller L, Miller JP, Williams MM, Kopan R, Behrens MI, Morris JC: Cancer linked to Alzheimer disease but not vascular dementia. Neurology 2010, 74:106-112.

19. Boffetta $\mathrm{P}$, Nordenvall C, Nyren O, Ye W: A prospective study of gout and cancer. Eur J Cancer Prev 2009, 18:127-132.

20. Braun S, Bitton-Worms K, Leroith D: The Link between the Metabolic Syndrome and Cancer. Int J Biol Sci 2011, 7:1003-1015.

21. Cheung N, Shankar A, Klein R, Folsom AR, Couper DJ, Wong TY: Agerelated macular degeneration and cancer mortality in the atherosclerosis risk in communities study. Arch Ophthalmol 2007, 125:1241-1247.

22. Derr RL, Ye X, Islas MU, Desideri S, Saudek CD, Grossman SA: Association between hyperglycemia and survival in patients with newly diagnosed glioblastoma. J Clin Oncol 2009, 27:1082-1086.

23. Goodwin PJ, Ennis M, Pritchard Kl, Trudeau ME, Koo J, Madarnas $Y$, Hartwick W, Hoffman B, Hood N: Fasting insulin and outcome in earlystage breast cancer: results of a prospective cohort study. J Clin Oncol 2002, 20:42-51.

24. Ma J, Li H, Giovannucci E, Mucci L, Qiu W, Nguyen PL, Gaziano JM, Pollak M, Stampfer MJ: Prediagnostic body-mass index, plasma C-peptide concentration, and prostate cancer-specific mortality in men with prostate cancer: a long-term survival analysis. Lancet Oncol 2008, 9:1039-1047

25. Stattin $P$, Bjor $O$, Ferrari $P$, Lukanova $A$, Lenner $P$, Lindahl $B$, Hallmans $G$, Kaaks R: Prospective study of hyperglycemia and cancer risk. Diabetes Care 2007, 30:561-567.

26. Weiser MA, Cabanillas ME, Konopleva M, Thomas DA, Pierce SA, Escalante CP, Kantarjian HM, O'Brien SM: Relation between the duration of remission and hyperglycemia during induction chemotherapy for acute lymphocytic leukemia with a hyperfractionated cyclophosphamide, vincristine, doxorubicin, and dexamethasone/methotrexate-cytarabine regimen. Cancer 2004, 100:1179-1185.

27. Wolpin BM, Meyerhardt JA, Chan AT, Ng K, Chan JA, Wu K, Pollak MN, Giovannucci EL, Fuchs CS: Insulin, the insulin-like growth factor axis, and mortality in patients with nonmetastatic colorectal cancer. J Clin Oncol 2009, 27:176-185.

28. Yuhara H, Steinmaus C, Cohen SE, Corley DA, Tei Y, Buffler PA: Is Diabetes Mellitus an Independent Risk Factor for Colon Cancer and Rectal Cancer? Am J Gastroenterol 2011.

29. Augustin LS, Dal Maso L, La Vecchia C, Parpinel M, Negri E, Vaccarella S, Kendall CW, Jenkins DJ, Francesch S: Dietary glycemic index and glycemic load, and breast cancer risk: a case-control study. Ann Oncol 2001, 12:1533-1538.

30. Melnik BC, John SM, Schmitz G: Over-stimulation of insulin/IGF1 signaling by Western diet may promote diseases of civilization: lessons learnt from Laron syndrome. Nutr Metab (Lond) 2011, 8:41

31. Sieri S, Pala V, Brighenti F, Pellegrini N, Muti P, Micheli A, Evangelista A, Grioni S, Contiero P, Berrino F, Krogh V: Dietary glycemic index, glycemic load, and the risk of breast cancer in an Italian prospective cohort study. Am J Clin Nutr 2007, 86:1160-1166.

32. Wen W, Shu XO, Li H, Yang G, Ji BT, Cai H, Gao YT, Zheng W: Dietary carbohydrates, fiber, and breast cancer risk in Chinese women. Am J Clin Nutr 2009, 89:283-289.

33. Braunstein A: Wratschebnaje obosrnije 1921, 7:291.

34. Bierich R: Über die Beteiligung des Bindegewebes an der experimentellen Krebsbildung. Virchows Archiv $f$ Pathol Anatom und Physiol 1922, 23:1-19.

35. Bierich R: Über die Vorgänge Beim Einwuchern der Krebszellen. Wien Klin Wochenschr 1927, 6:1599-1603.

36. Warburg O: Über den Stoffwechsel der Carzinomzelle. Klinische Wochenschrift 1925, 534-536.

37. Warburg O, Posener K, Negelein E: Über den Stoffwechsel der Carcinomzelle. Biochem Zeitschr 1924, 309-344.

38. Warburg O, Wind F, Negelein E: Über den Stoffwechsel der Tumoren im Körper. Klinische Wochenschrift 1926, 828-832.
39. Hanahan D, Weinberg RA: Hallmarks of cancer: the next generation. Cell 2011, 144:646-674

40. Seyfried TN, Shelton LM: Cancer as a metabolic disease. Nutr Metab (Lond) 2010, 7:7.

41. Warburg O: On respiratory impairment in cancer cells. Science 1956, 124:269-270.

42. Pelicano H, Xu RH, Du M, Feng L, Sasaki R, Carew JS, Hu Y, Ramdas L, Hu L, Keating MJ, et al: Mitochondrial respiration defects in cancer cells cause activation of Akt survival pathway through a redox-mediated mechanism. J Cell Biol 2006, 175:913-923.

43. Robey RB, Hay N: Mitochondrial hexokinases, novel mediators of the antiapoptotic effects of growth factors and Akt. Oncogene 2006, 25:4683-4696.

44. Robey RB, Hay N: Is Akt the "Warburg kinase"?-Akt-energy metabolism interactions and oncogenesis. Semin Cancer Biol 2009, 19:25-31.

45. Young CD, Anderson SM: Sugar and fat - that's where it's at: metabolic changes in tumors. Breast Cancer Res 2008, 10:202.

46. Deberardinis RJ, Lum JJ, Thompson CB: Phosphatidylinositol 3-kinasedependent modulation of carnitine palmitoyltransferase $1 \mathrm{~A}$ expression regulates lipid metabolism during hematopoietic cell growth. J Biol Chem 2006, 281:37372-37380

47. Berwick DC, Hers I, Heesom KJ, Moule SK, Tavare JM: The identification of ATP-citrate lyase as a protein kinase B (Akt) substrate in primary adipocytes. J Biol Chem 2002, 277:33895-33900.

48. Schwertfeger KL, McManaman JL, Palmer CA, Neville MC, Anderson SM: Expression of constitutively activated Akt in the mammary gland leads to excess lipid synthesis during pregnancy and lactation. J Lipid Res 2003, 44:1100-1112.

49. Laplante M, Sabatini DM: mTOR signaling at a glance. J Cell Sci 2009, 122:3589-3594

50. Mamane $Y$, Petroulakis E, LeBacquer O, Sonenberg N: mTOR, translation initiation and cancer. Oncogene 2006, 25:6416-6422.

51. Sun $Q$, Chen $X, M a J$, Peng $H$, Wang $F$, Zha $X$, Wang $Y$, Jing $Y$, Yang $H$, Chen $R$, et al: Mammalian target of rapamycin up-regulation of pyruvate kinase isoenzyme type $\mathrm{M} 2$ is critical for aerobic glycolysis and tumor growth. Proc Natl Acad Sci USA 2011, 108:4129-4134.

52. Zha X, Sun $Q$, Zhang $H$ : mTOR upregulation of glycolytic enzymes promotes tumor development. Cell Cycle 2011, 10:1015-1016.

53. Koppenol WH, Bounds PL, Dang CV: Otto Warburg's contributions to current concepts of cancer metabolism. Nat Rev Cancer 2011, 11:325-337.

54. Cully M, You H, Levine AJ, Mak TW: Beyond PTEN mutations: the PI3K pathway as an integrator of multiple inputs during tumorigenesis. Nat Rev Cancer 2006, 6:184-192.

55. Choi NC, Fischman AJ, Niemierko A, Ryu JS, Lynch T, Wain J, Wright C, Fidias $P$, Mathisen D: Dose-response relationship between probability of pathologic tumor control and glucose metabolic rate measured with FDG PET after preoperative chemoradiotherapy in locally advanced nonsmall-cell lung cancer. Int J Radiat Oncol Biol Phys 2002, 54:1024-1035.

56. Kunkel $M$, Reichert TE, Benz $P$, Lehr HA, Jeong JH, Wieand S, Bartenstein $P$, Wagner W, Whiteside TL: Overexpression of Glut-1 and increased glucose metabolism in tumors are associated with a poor prognosis in patients with oral squamous cell carcinoma. Cancer 2003, 97:1015-1024.

57. Bentzen SM, Gregoire V: Molecular imaging-based dose painting: a novel paradigm for radiation therapy prescription. Semin Radiat Oncol 2011, 21:101-110.

58. LeRoith D: Can endogenous hyperinsulinaemia explain the increased risk of cancer development and mortality in type 2 diabetes: evidence from mouse models. Diabetes Metab Res Rev 2010, 26:599-601.

59. Huang XF, Chen JZ: Obesity, the PI3K/Akt signal pathway and colon cancer. Obes Rev 2009, 10:610-616.

60. Pollak M: Insulin and insulin-like growth factor signalling in neoplasia. Nat Rev Cancer 2008, 8:915-928.

61. Fontana $L$, Partridge $L$, Longo VD: Extending healthy life span-from yeast to humans. Science 2010, 328:321-326.

62. Lee C, Longo VD: Fasting vs dietary restriction in cellular protection and cancer treatment: from model organisms to patients. Oncogene 2011, 30:3305-3316.

63. Bloom WL, Azar GJ: Similarities Of Carbohydrate Deficiency And Fasting. I. Weight Loss, Electrolyte Excretion, And Fatigue. Arch Intern Med 1963, 112:333-337. 
64. Fery F, Bourdoux P, Christophe J, Balasse EO: Hormonal and metabolic changes induced by an isocaloric isoproteinic ketogenic diet in healthy subjects. Diabete Metab 1982, 8:299-305.

65. Klein S, Wolfe RR: Carbohydrate restriction regulates the adaptive response to fasting. Am J Physiol 1992, 262:E631-636.

66. Azar GJ, Bloom WL: Similarities Of Carbohydrate Deficiency And Fasting. li. Ketones, Nonesterified Fatty Acids And Nitrogen Excretion. Arch Intern Med 1963, 112:338-343.

67. Jiang $W$, Zhu Z, Thompson HJ: Dietary energy restriction modulates the activity of AMP-activated protein kinase, Akt, and mammalian target of rapamycin in mammary carcinomas, mammary gland, and liver. Cancer Res 2008, 68:5492-5499.

68. Walenta S, Wetterling M, Lehrke M, Schwickert G, Sundfor K, Rofstad EK, Mueller-Klieser W: High lactate levels predict likelihood of metastases, tumor recurrence, and restricted patient survival in human cervical cancers. Cancer Res 2000, 60:916-921.

69. Gatenby RA, Smallbone K, Maini PK, Rose F, Averill J, Nagle RB, Worrall L, Gillies RJ: Cellular adaptations to hypoxia and acidosis during somatic evolution of breast cancer. Br J Cancer 2007, 97:646-653.

70. Bonuccelli G, Tsirigos A, Whitaker-Menezes D, Pavlides S, Pestell RG, Chiavarina B, Frank PG, Flomenberg N, Howell A, Martinez-Outschoorn UE, et al: Ketones and lactate "fuel" tumor growth and metastasis: Evidence that epithelial cancer cells use oxidative mitochondrial metabolism. Cell Cycle 2010, 9:3506-3514.

71. Semenza GL: Tumor metabolism: cancer cells give and take lactate. J Clin Invest 2008, 118:3835-3837.

72. Baumann F, Leukel P, Doerfelt A, Beier CP, Dettmer K, Oefner PJ, Kastenberger M, Kreutz M, Nickl-Jockschat T, Bogdahn U, et al: Lactate promotes glioma migration by TGF-beta2-dependent regulation of matrix metalloproteinase-2. Neuro Oncol 2009, 11:368-380.

73. Chaussain-Miller C, Fioretti F, Goldberg M, Menashi S: The role of matrix metalloproteinases (MMPs) in human caries. J Dent Res 2006, 85:22-32.

74. Williams AC, Collard TJ, Paraskeva C: An acidic environment leads to p53 dependent induction of apoptosis in human adenoma and carcinoma cell lines: implications for clonal selection during colorectal carcinogenesis. Oncogene 1999, 18:3199-3204.

75. Park HJ, Lyons JC, Ohtsubo T, Song CW: Acidic environment causes apoptosis by increasing caspase activity. Br J Cancer 1999, 80:1892-1897.

76. Gatenby RA, Gawlinski ET, Gmitro AF, Kaylor B, Gillies RJ: Acid-mediated tumor invasion: a multidisciplinary study. Cancer Res 2006, 66:5216-5223.

77. Fang JS, Gillies RD, Gatenby RA: Adaptation to hypoxia and acidosis in carcinogenesis and tumor progression. Semin Cancer Biol 2008, 18:330-337.

78. Demetrakopoulos GE, Linn B, Amos H: Rapid loss of ATP by tumor cells deprived of glucose: contrast to normal cells. Biochem Biophys Res Commun 1978, 82:787-794.

79. Priebe A, Tan L, Wahl H, Kueck A, He G, Kwok R, Opipari A, Liu JR: Glucose deprivation activates AMPK and induces cell death through modulation of Akt in ovarian cancer cells. Gynecol Oncol 2011, 122:389-95.

80. Shim H, Chun YS, Lewis BC, Dang CV: A unique glucose-dependent apoptotic pathway induced by C-Myc. Proc Natl Acad Sci USA 1998, 95:1511-1516.

81. Masur K, Vetter C, Hinz A, Tomas N, Henrich H, Niggemann B, Zanker KS: Diabetogenic glucose and insulin concentrations modulate transcriptome and protein levels involved in tumour cell migration, adhesion and proliferation. Br J Cancer 2011, 104:345-352.

82. Gatenby RA, Gillies RJ: Why do cancers have high aerobic glycolysis? Nat Rev Cancer 2004, 4:891-899.

83. Santisteban GA, Ely JT, Hamel EE, Read DH, Kozawa SM: Glycemic modulation of tumor tolerance in a mouse model of breast cancer. Biochem Biophys Res Commun 1985, 132:1174-1179.

84. Seyfried TN, Sanderson TM, El-Abbadi MM, McGowan R, Mukherjee P: Role of glucose and ketone bodies in the metabolic control of experimental brain cancer. Br J Cancer 2003, 89:1375-1382.

85. Koroljow S: Two cases of malignant tumors with metastases apparently treated successfully with hypoglycemic coma. Psychiatr Q 1962, 36:261-270.

86. McGirt MJ, Chaichana KL, Gathinji M, Attenello F, Than K, Ruiz AJ, Olivi A, Quinones-Hinojosa A: Persistent outpatient hyperglycemia is independently associated with decreased survival after primary resection of malignant brain astrocytomas. Neurosurgery 2008, 63:286-291, discussion 291.

87. Maestu I, Pastor M, Gomez-Codina J, Aparicio J, Oltra A, Herranz C, Montalar J, Munarriz B, Reynes G: Pretreatment prognostic factors for survival in small-cell lung cancer: a new prognostic index and validation of three known prognostic indices on 341 patients. Ann Oncol 1997, 8:547-553.

88. Krone CA, Ely JT: Controlling hyperglycemia as an adjunct to cancer therapy. Integr Cancer Ther 2005, 4:25-31.

89. Jee SH, Ohrr H, Sull JW, Yun JE, Ji M, Samet JM: Fasting serum glucose level and cancer risk in Korean men and women. Jama 2005, 293:194-202.

90. Ikeda F, Doi Y, Yonemoto K, Ninomiya T, Kubo M, Shikata K, Hata J, Tanizaki Y, Matsumoto T, lida M, Kiyohara Y: Hyperglycemia increases risk of gastric cancer posed by Helicobacter pylori infection: a populationbased cohort study. Gastroenterology 2009, 136:1234-1241.

91. Ely JT, Krone CA: Glucose and cancer. N Z Med J 2002, 115:U123.

92. Shanmugam N, Reddy MA, Guha M, Natarajan R: High glucose-induced expression of proinflammatory cytokine and chemokine genes in monocytic cells. Diabetes 2003, 52:1256-1264.

93. Wen Y, Gu J, Li SL, Reddy MA, Natarajan R, Nadler JL: Elevated glucose and diabetes promote interleukin-12 cytokine gene expression in mouse macrophages. Endocrinology 2006, 147:2518-2525.

94. Dandona P, Chaudhuri A, Ghanim H, Mohanty P: Proinflammatory effects of glucose and anti-inflammatory effect of insulin: relevance to cardiovascular disease. Am J Cardiol 2007, 99:15B-26B.

95. Rajaram S, Baylink DJ, Mohan S: Insulin-like growth factor-binding proteins in serum and other biological fluids: regulation and functions. Endocr Rev 1997, 18:801-831.

96. LaPensee CR, Hugo ER, Ben-Jonathan N: Insulin stimulates interleukin-6 expression and release in LS14 human adipocytes through multiple signaling pathways. Endocrinology 2008, 149:5415-5422.

97. Venkateswaran V, Haddad AQ, Fleshner NE, Fan R, Sugar LM, Nam R, Klotz LH, Pollak M: Association of diet-induced hyperinsulinemia with accelerated growth of prostate cancer (LNCaP) xenografts. J Natl Cancer Inst 2007, 99:1793-1800.

98. Goodwin PJ, Ennis M, Pritchard Kl, Trudeau ME, Koo J, Hartwick W, Hoffma B, Hood N: Insulin-like growth factor binding proteins 1 and 3 and breast cancer outcomes. Breast Cancer Res Treat 2002, 74:65-76.

99. Freund E: Zur Diagnose des Carcinoms. Wien med B/ 1885, 1:268-269.

100. Lundholm K, Holm G, Schersten T: Insulin resistance in patients with cancer. Cancer Res 1978, 38:4665-4670.

101. McCall JL, Tuckey JA, Parry BR: Serum tumour necrosis factor alpha and insulin resistance in gastrointestinal cancer. Br J Surg 1992, 79:1361-1363.

102. Marat D, Noguchi Y, Yoshikawa T, Tsuburaya A, Ito T, Kondo J: Insulin resistance and tissue glycogen content in the tumor-bearing state. Hepatogastroenterology 1999, 46:3159-3165.

103. Makino T, Noguchi Y, Yoshikawa T, Doi C, Nomura K: Circulating interleukin 6 concentrations and insulin resistance in patients with cancer. Br J Surg 1998, 85:1658-1662.

104. Yoshikawa T, Noguchi Y, Matsumoto A: Effects of tumor removal and body weight loss on insulin resistance in patients with cancer. Surgery 1994, 116:62-66.

105. Permert J, Ihse I, Jorfeldt L, von Schenck H, Arnquist HJ, Larsson J: Improved glucose metabolism after subtotal pancreatectomy for pancreatic cancer. Br J Surg 1993, 80:1047-1050.

106. Waterhouse C, Jeanpretre N, Keilson J: Gluconeogenesis from alanine in patients with progressive malignant disease. Cancer Res 1979, 39:1968-1972.

107. Rich AJ, Wright PD: Ketosis and nitrogen excretion in undernourished surgical patients. JPEN J Parenter Enteral Nutr 1979, 3:350-354.

108. Conyers RA, Need AG, Rofe AM, Potezny N, Kimber RJ: Nutrition and cancer. Br Med J 1979, 1:1146.

109. Owen OE, Morgan AP, Kemp HG, Sullivan JM, Herrera MG, Cahill GF Jr: Brain metabolism during fasting. J Clin Invest 1967, 46:1589-1595.

110. Gambardella A, Paolisso G, D’Amore A, Granato M, Verza M, Varricchio M: Different contribution of substrates oxidation to insulin resistance in malnourished elderly patients with cancer. Cancer 1993, 72:3106-3113.

111. Korber J, Pricelius S, Heidrich M, Muller MJ: Increased lipid utilization in weight losing and weight stable cancer patients with normal body weight. Eur J Clin Nutr 1999, 53:740-745. 
112. Young VR: Energy metabolism and requirements in the cancer patient. Cancer Res 1977, 37:2336-2347.

113. Tisdale MJ, Brennan RA: Loss of acetoacetate coenzyme A transferase activity in tumours of peripheral tissues. Br J Cancer 1983, 47:293-297.

114. Zhou W, Mukherjee P, Kiebish MA, Markis WT, Mantis JG, Seyfried TN: The calorically restricted ketogenic diet, an effective alternative therapy for malignant brain cancer. Nutr Metab (Lond) 2007, 4:5

115. Conyers RA, Need AG, Durbridge T, Harvey ND, Potezny N, Rofe AM: Cancer, ketosis and parenteral nutrition. Med J Aust 1979, 1:398-399.

116. Magee BA, Potezny N, Rofe AM, Conyers RA: The inhibition of malignant cell growth by ketone bodies. Aust J Exp Biol Med Sci 1979, 57:529-539.

117. Freeman JM, Kossoff EH: Ketosis and the ketogenic diet, 2010: advances in treating epilepsy and other disorders. Adv Pediatr 2010, 57:315-329.

118. Westman EC, Feinman RD, Mavropoulos JC, Vernon MC, Volek JS, Wortman JA, Yancy WS, Phinney SD: Low-carbohydrate nutrition and metabolism. Am J Clin Nutr 2007, 86:276-284.

119. Kossoff EH, Dorward JL: The modified Atkins diet. Epilepsia 2008, 49(Suppl 8):37-41

120. Fearon KC, Tisdale MJ, Preston T, Plumb JA, Calman KC: Failure of systemic ketosis to control cachexia and the growth rate of the Walker 256 carcinosarcoma in rats. Br J Cancer 1985, 52:87-92.

121. Tisdale MJ, Brennan RA, Fearon KC: Reduction of weight loss and tumour size in a cachexia model by a high fat diet. Br J Cancer 1987, 56:39-43.

122. Tisdale MJ, Brennan RA: A comparison of long-chain triglycerides and medium-chain triglycerides on weight loss and tumour size in a cachexia model. Br J Cancer 1988, 58:580-583.

123. Beck SA, Tisdale MJ: Effect of insulin on weight loss and tumour growth in a cachexia model. Br J Cancer 1989, 59:677-681.

124. Händel M, Tadeuma K: Über die Beziehung des Geschwulstwachstums zur Ernährung und zum Stoffwechsel. II. Mitteilung. Versuche zur Frage der Bedeutung der Kohlenhydrate für das Wachstum des Rattencarcinoms. Klin Wochenschr 1924, 288-293.

125. Fearon KC, Borland W, Preston T, Tisdale MJ, Shenkin A, Calman KC: Cancer cachexia: influence of systemic ketosis on substrate levels and nitrogen metabolism. Am J Clin Nutr 1988, 47:42-48.

126. Breitkreutz $R$, Tesdal $K$, Jentschura $D$, Haas $\mathrm{O}$, Leweling $\mathrm{H}$, Holm E: Effects of a high-fat diet on body composition in cancer patients receiving chemotherapy: a randomized controlled study. Wien Klin Wochenschr 2005, 117:685-692

127. Fine EJ MA, Quadros EV, Sequeira JM, Feinman RD: Acetoacetate reduces growth and ATP concentration in cancer cell lines which over-express uncoupling protein 2. Cancer Cell international 2009, 9:14:11.

128. Maurer GD, Brucker DP, Baehr O, Harter PN, Hattingen E, Walenta S, Mueller-Klieser W, Steinbach JP, Rieger J: Differential utilization of ketone bodies by neurons and glioma cell lines: a rationale for ketogenic diet as experimental glioma therapy. BMC Cancer 2011, 11:315.

129. van Ness van Alstyne E, Beebe SP: Diet studies in transplantable tumors. I. The effect of non-carbohydrate diet upon the growth of transplantable sarcoma in rats. J Med Res 1913, 217-232.

130. Otto C, Kaemmerer U, Illert B, Muehling B, Pfetzer N, Wittig R, Voelker HU, Thiede A, Coy JF: Growth of human gastric cancer cells in nude mice is delayed by a ketogenic diet supplemented with omega- 3 fatty acids and medium-chain triglycerides. BMC Cancer 2008, 8:122.

131. Ho WW, Leung K, Hsu A, Luk B, Lai J, Shen SY, Minchinton Al, Waterhouse D, Bally MB, Lin W, et al: A Low Carbohydrate, High Protein Diet Slows Tumor Growth and Prevents Cancer Initiation. Cancer Res 2011.

132. Zuccoli G, Marcello N, Pisanello A, Servadei F, Vaccaro S, Mukherjee P, Seyfried TN: Metabolic management of glioblastoma multiforme using standard therapy together with a restricted ketogenic diet: Case Report. Nutr Metab (Lond) 2010, 7:33.

133. Tannenbaum A: The Genesis and Growth of Tumors. II. Effects of Caloric Restriction per se. Cancer Res 1942, 2:460-467.

134. Freedland SJ, Mavropoulos J, Wang A, Darshan M, Demark-Wahnefried W, Aronson WJ, Cohen P, Hwang D, Peterson B, Fields T, et al: Carbohydrate restriction, prostate cancer growth, and the insulin-like growth factor axis. Prostate 2008, 68:11-19.

135. Masko EM, Thomas JA, Antonelli JA, Lloyd JC, Phillips TE, Poulton SH, Dewhirst MW, Pizzo SV, Freedland SJ: Low-carbohydrate diets and prostate cancer: how low is "low enough"? Cancer Prev Res (Phila) 2010, 3:1124-1131
136. Fine EJ, Segal-Isaacson CJ, Feinman RD, Herszkopf S, Romano M, Tomuta N, Bontempo A, Sparano JA: A pilot safety and feasibility trial of a reduced carbohydrate diet in patients with advanced cancer. J Clin Oncol 2011, 29(suppl; abstr e13573).

137. Rossi-Fanelli F, Franchi F, Mulieri M, Cangiano C, Cascino A, Ceci F, Muscaritoli M, Seminara P, Bonomo L: Effect of energy substrate manipulation on tumour cell proliferation in parenterally fed cancer patients. Clin Nutr 1991, 10:228-232.

138. Schmidt M, Pfetzer N, Schwab M, Strauss I, Kammerer U: Effects of a ketogenic diet on the quality of life in 16 patients with advanced cancer: A pilot trial. Nutr Metab (Lond) 2011, 8:54.

139. Nebeling LC, Miraldi F, Shurin SB, Lerner E: Effects of a ketogenic diet on tumor metabolism and nutritional status in pediatric oncology patients: two case reports. J Am Coll Nutr 1995, 14:202-208.

140. Nebeling LC, Lerner E: Implementing a ketogenic diet based on mediumchain triglyceride oil in pediatric patients with cancer. J Am Diet Assoc 1995, 95:693-697.

141. Rieger J, Baehr O, Hattingen E, Maurer G, Coy J, Weller M, Steinbach J: The ERGO trial: A pilot study of a ketogenic diet in patients with recurrent glioblastoma. J Clin Oncol (Meeting Abstracts) 2010, 28:e12532.

142. Fine EJ, Segal-Isaacson CJ, Feinman R, Sparano J: Carbohydrate restriction in patients with advanced cancer: a protocol to assess safety and feasibility with an accompanying hypothesis. Commun Oncol 2008, 5:22-26.

143. Moulton CJ, Valentine RJ, Layman DK, Devkota S, Singletary KW, Wallig MA, Donovan SM: A high protein moderate carbohydrate diet fed at discrete meals reduces early progression of $\mathrm{N}$-methyl-N-nitrosourea-induced breast tumorigenesis in rats. Nutr Metab (Lond) 2010, 7:1.

144. Osborne CK, Bolan G, Monaco ME, Lippman ME: Hormone responsive human breast cancer in long-term tissue culture: effect of insulin. Proc Natl Acad Sci USA 1976, 73:4536-4540.

145. Jonsson T, Granfeldt Y, Erlanson-Albertsson C, Ahren B, Lindeberg S: A paleolithic diet is more satiating per calorie than a mediterranean-like diet in individuals with ischemic heart disease. Nutr Metab (Lond) 2010, 7:85.

146. Nickols-Richardson SM, Coleman MD, Volpe JJ, Hosig KW: Perceived hunger is lower and weight loss is greater in overweight premenopausal women consuming a low-carbohydrate/high-protein vs high-carbohydrate/low-fat diet. J Am Diet Assoc 2005, 105:1433-1437.

147. Mavropoulos JC, Isaacs WB, Pizzo SV, Freedland SJ: Is there a role for a low-carbohydrate ketogenic diet in the management of prostate cancer? Urology 2006, 68:15-18.

148. Mantovani A, Allavena P, Sica A, Balkwill F: Cancer-related inflammation. Nature 2008, 454:436-444.

149. Gonzalez F, Minium J, Rote NS, Kirwan JP: Altered tumor necrosis factor alpha release from mononuclear cells of obese reproductive-age women during hyperglycemia. Metabolism 2006, 55:271-276.

150. Depner CM, Kirwan RD, Frederickson SJ, Miles MP: Enhanced inflammation with high carbohydrate intake during recovery from eccentric exercise. Eur J Appl Physiol 2010, 109:1067-1076.

151. Rudnick PA, Taylor KW: Effect Of Prolonged Carbohydrate Restriction On Serum-Insulin Levels In Mild Diabetes. Br Med J 1965, 1:1225-1228.

152. Garg A, Bantle JP, Henry RR, Coulston AM, Griver KA, Raatz SK, Brinkley L, Chen YD, Grundy SM, Huet BA, et al: Effects of varying carbohydrate content of diet in patients with non-insulin-dependent diabetes mellitus. Jama 1994, 271:1421-1428.

153. Accurso A, Bernstein RK, Dahlqvist A, Draznin B, Feinman RD, Fine EJ, Gleed A, Jacobs DB, Larson G, Lustig RH, et al: Dietary carbohydrate restriction in type 2 diabetes mellitus and metabolic syndrome: time for a critical appraisal. Nutr Metab (Lond) 2008, 5:9.

154. Perez-Guisado J, Munoz-Serrano A, Alonso-Moraga A: Spanish Ketogenic Mediterranean Diet: a healthy cardiovascular diet for weight loss. Nutr J 2008, 7:30

155. Volek JS, Phinney SD, Forsythe CE, Quann EE, Wood RJ, Puglisi MJ, Kraemer WJ, Bibus DM, Fernandez ML, Feinman RD: Carbohydrate restriction has a more favorable impact on the metabolic syndrome than a low fat diet. Lipids 2009, 44:297-309.

156. Jonsson T, Granfeldt Y, Ahren B, Branell UC, Palsson G, Hansson A, Soderstrom M, Lindeberg S: Beneficial effects of a Paleolithic diet on cardiovascular risk factors in type 2 diabetes: a randomized cross-over pilot study. Cardiovasc Diabetol 2009, 8:35. 
157. Elhayany A, Lustman A, Abel R, Attal-Singer J, Vinker S: A low carbohydrate Mediterranean diet improves cardiovascular risk factors and diabetes control among overweight patients with type 2 diabetes mellitus: a 1year prospective randomized intervention study. Diabetes Obes Metab 2010, 12:204-209.

158. Forsythe CE, Phinney SD, Fernandez ML, Quann EE, Wood RJ, Bibus DM, Kraemer WJ, Feinman RD, Volek JS: Comparison of low fat and low carbohydrate diets on circulating fatty acid composition and markers of inflammation. Lipids 2008, 43:65-77.

159. Cordain L: Cereal grains: humanity's double-edged sword. World Rev Nutr Diet 1999, 84:19-73.

160. Cordain L, Toohey L, Smith MJ, Hickey MS: Modulation of immune function by dietary lectins in rheumatoid arthritis. Br J Nutr 2000, 83:207-217.

161. Fasano A: Zonulin and its regulation of intestinal barrier function: the biological door to inflammation, autoimmunity, and cancer. Physiol Rev 2011, 91:151-175.

162. Klonoff DC: The beneficial effects of a Paleolithic diet on type 2 diabetes and other risk factors for cardiovascular disease. J Diabetes Sci Technol 2009, 3:1229-1232.

doi:10.1186/1743-7075-8-75

Cite this article as: Klement and Kämmerer: Is there a role for carbohydrate restriction in the treatment and prevention of cancer? Nutrition \& Metabolism 2011 8:75.

\section{Submit your next manuscript to BioMed Central and take full advantage of:}

- Convenient online submission

- Thorough peer review

- No space constraints or color figure charges

- Immediate publication on acceptance

- Inclusion in PubMed, CAS, Scopus and Google Scholar

- Research which is freely available for redistribution

Submit your manuscript at www.biomedcentral.com/submit 